\title{
INCREASING FAILURE RATE AFTER USING THE SAME PREPARATION AND DOSAGE OF PENICILLIN IN THE TREATMENT OF GONORRHOEA*
}

BY

\author{
H. C. GJESSING
}

Bureau of Public Health, Oslo

In 1949, in reporting the treatment of gonorrhoea with the penicillin preparations, two cases of relapse that required very large doses before a cure was effected were mentioned (Gjessing, 1949, 1951). Sensitivity tests were not carried out in these cases. A later communication (Gjessing, 1956) discussed the results in 1,115 males treated with several more modern preparations between January 3, 1949, and September 12, 1955. The active compound in all these preparations was procaine-penicillin and the dose in all cases consisted of one injection of 300,000 units. Three different preparations were used in all but 77 cases (Table I) and the percentage of relapses $\dagger$

TABLE I

RESULTS OF TREATMENT AT DIFFERENT TIMES WITH DIFFERENT PENICILLIN PREPARATIONS

\begin{tabular}{|c|c|c|c|c|}
\hline Preparation & $\begin{array}{l}\text { Dosage } \\
\text { (units) }\end{array}$ & $\begin{array}{c}\text { No. of } \\
\text { Patients }\end{array}$ & Period of Time & $\begin{array}{l}\text { Percent- } \\
\text { age of } \\
\text { Relapses }\end{array}$ \\
\hline $\begin{array}{ll}\text { Duracillin } \quad . . \\
\end{array}$ & 300,000 & 321 & 3. $1.49-29.6 .50$ & $2 \cdot 2$ to $2 \cdot 9$ \\
\hline Duracillin AS & 300,000 & 326 & $6.10 .50-29.10 .52$ & $2 \cdot 8$ to $3 \cdot 7$ \\
\hline $\begin{array}{l}\text { Procain-Penicil- } \\
\text { lin G. Novo }\end{array}$ & 300,000 & 391 & 4.11.52-12. 9.55 & 3.0 to $4 \cdot 1$ \\
\hline
\end{tabular}

* Received for publication June 29, 1959.

$\dagger$ The percentage of relapses is based on the total patients treated (first figure) and the number of cases followed-up for one or more weeks (second figure). The first figure is probably too low while the second is too high, because many patients who are in fact cured do not return for re-examination. The accurate percentage of relapses return for re-examination. The accurate percentage
probably lies somewhere between these two figures. gradually increased during the period in question. Increasing penicillin resistance and the use of different penicillin preparations were suggested as possible causes.

Procaine-penicillin G.Novo (Prok. pen. G.N.) continued to be used until November 24, 1955, by which date 463 patients had been treated with the same preparation and dose. After several other preparations $\ddagger$ had been tried, a new study was made with Prok. pen. G.N. in a further 28 cases. Thus a total of 491 males received the same preparation in the same dosage (Table II).

In the first period 2 to $2 \cdot 6$ per cent. of 305 patients relapsed.

In the following period the failure rate in 158 cases was 7 to 9 per cent. and, if the 28 patients treated at the end of 1957 were added, the percentage of relapses was $8 \cdot 6$ to 11 per cent.

In these groups the same dose and preparation of penicillin had been used throughout and the increased relapse rate indicates that the efficacy of 300,000 units had diminished.

Relapse or Re-infection.-We tried to re-examine our patients microscopically once a week for a

$\ddagger$ Duracillin Fortified, dose 400,000 U.: 185 patients, four relapses Duropenin Simplex, dose 300,000 U.: 86 patients, three relapses Bristol P.A.M. and Avloprocil P.A.M., dose 300,000 U.: 118 patients eight relapses.

TABLE II

COMPARISON OF EFFICACY OF SAME PREPARATION AND DOSAGE AT DIFFERENT DATES

\begin{tabular}{|c|c|c|c|c|c|c|c|c|c|}
\hline \multirow{2}{*}{ Preparation (Dosage) } & \multirow{2}{*}{ Period of Time } & \multirow{2}{*}{$\begin{array}{c}\text { No. of } \\
\text { Patients }\end{array}$} & \multicolumn{4}{|c|}{ Follow-Up (days) } & \multirow{2}{*}{$\begin{array}{c}\text { Re- } \\
\text { lapses }\end{array}$} & \multirow{2}{*}{$\begin{array}{c}\text { Rein- } \\
\text { fections }\end{array}$} & \multirow{2}{*}{$\begin{array}{l}\text { Percentage } \\
\text { of Relapses }\end{array}$} \\
\hline & & & 0 & $7-13$ & $14-19$ & $\begin{array}{l}30 \text { or } \\
\text { More }\end{array}$ & & & \\
\hline \multirow{3}{*}{$\begin{array}{l}\text { Procain-Penicillin } \\
\text { G.Novo } \\
(300,000 \text { units })\end{array}$} & $4.11 .52--31.12 .54$ & 305 & 78 & 18 & 21 & 173 & 6 & 9 & $2-2 \cdot 6$ \\
\hline & 2. $1.55-24.11 .55$ & 158 & 37 & 8 & 15 & 85 & 11 & 2 & \multirow{2}{*}{$8 \cdot 6-11$} \\
\hline & $26.10 .57-30.12 .57$ & 28 & 3 & 1 & 0 & 19 & 5 & - & \\
\hline
\end{tabular}


month, but often had to be content with less. To assess the efficacy of treatment it is important to distinguish as far as possible between relapse and re-infection, because re-infection is not due to failure of treatment.

Relapses generally occur within 1 or 2 weeks after treatment. Suspicion of re-infection increases with the length of the gonococcus-free interval between the completed treatment and the new demonstration of the gonococcus.

When the patient admits sexual intercourse during the follow-up period and the symptoms appear at the appropriate time, re-infection is indicated. When fresh exposure occurs just after treatment the return of symptoms may be due to re-infection, but may equally well be due to relapse, and such cases should usually be considered as relapses. In the present study (Table II), eleven patients are regarded as having been re-infected, and six of them admitted sexual intercourse during the follow-up period.

Causes of Relapse.-These must be sought in the patient, the preparation, or the gonococcus.

It is my impression that alcohol taken, even in small amounts, during the first week after treatment favours the development of relapse. Patients are therefore advised against taking beer, wine, or spirits during the first week after treatment. There is however, no reason to believe that the increased failure rate was accompanied by an increased use of alcohol.

Previously (Gjessing, 1956) no correlation was found between the incidence of relapse and the number of past gonococcal infections in an individual treated with penicillin; in other words a patient previously treated several times is not likely to have less chance of cure than one treated for the first time. As far as is known, penicillinase or other factors that may counteract or reduce the effect of penicillin have not yet been found in man.

Thus, for the present, there is nothing to indicate that the cause of the increasing incidence of relapse lies in the patient.

It is known that the earlier penicillin preparations gave poorer results than procaine-penicillin, but the increasing failure rate reported here cannot be due to any change in the penicillin as the same preparation and dosage were used throughout.

The third factor is the gonococcus, and it is now generally accepted that the increasing incidence of relapse is largely due to the development of relatively resistant strains. On the other hand some cases are still cured by a comparatively small amount of penicillin although bacteriological examination has shown a relative decrease of sensitivity. This fact still requires an explanation.

Increased Dosage.-When it was observed in January, 1958, that a dose of 300,000 units was insufficient, one injection of 600,000 units procainepenicillin became the routine dosage, and since September, 1958, the sensitivity of gonococcal strains has always been tested for each case before treatment was started. It is hoped to publish the results of this schedule of treatment and of the sensitivity tests in a future communication. To date (May, 1959) 255 males have been treated in this way with five relapses and four re-infections.

\section{Summary}

In Oslo the failure rate after the treatment of gonorrhoea with penicillin has increased 3- to 4-fold during a period of about 3 years .From November 4 , 1952, to December 31, 1954, a series of 305 males were treated with 300,000 units procaine-penicillin and the failure rate was 2 to $2 \cdot 6$ per cent. From January 2, 1955, to November 24, 1955, 158 men were treated and the failure rate was 7 to 9 per cent.; if 28 patients treated at the end of 1957 are added (total 186) the incidence of relapses is 8.6 to 11 per cent. (Table II).

It is emphasized that all patients received the same preparation and dosage of penicillin, so that a change in the preparation or dosage cannot be held responsible for the increased percentage of relapses in the present series.

The diagnosis of relapse or re-infection and the possible causes of relapse are briefly discussed.

As a consequence of the increasing failure rate the dosage for male patients was raised to 600,000 units procaine-penicillin from January, 1958. Since September, 1958, the penicillin sensitivity of gonococcal strains has been tested in all cases before treatment was started.

\section{REFERENCES}

Gjessing, H. C. (1949). T. norske Laegefor., 69, 538 (1951). Acta derm.-venereol. (Stockh.), 31, 249. 